\title{
PROCEEDINGS OF CBU
}

\section{CBU International Conference Proceedings 2013:}

\section{Integration and Innovation in Science and Education}

\section{Editors:}

Petr Hájek

Marie Zemková

\section{7-14 April 2013 \\ Prague, Czech Republic}

Organized by

Central Bohemia University, o.p.s., Prague, Czech Republic

Unicorn College s.r.o., Prague

Sponsored by

National Center of Hygiene and Occupational Diseases, Kazakhstan

Publisher

Central Bohemia University, o.p.s., Prague, Czech Republic

Proceedings of CBU 1805-9961, Vol. 1

Central Bohemia University is a nonprofit private university.

www.cbuni.cz

International Conference on Integration and Innovation in Science and Education 2013: edited by Petr Hájek, Marie Zemková, Proc. of CBU Vol. 1,

E-ISSN 1805-9961 (Online).

\section{http://dx.doi.org/10.12955/cbup.v1.675}


As this is a serial book published annually, it has both ISSN and ISBN. ISSN links to whole series of proceedings based on CBU International Conferences while ISBN links to this specific issue in 2013. Each article has also its own unique permanent DOI number which is located on the first page. A digital object identifier (DOI) is a unique alphanumeric string to identify content and provide a persistent link to its location on the internet. All DOI numbers begin with a 10 and contain a prefix and a sufix separeted by a slash. The prefix is number of four or more digits assigned to organizations; the sufix is assigned by the publisher. All articles were peer reviewed.

Please use the following format to cite material from this book:

Author, A., A. \& Author, B., B. (2013). TITTLE OF PAPER. CBU International Conference

Proceedings, 1. doi: Article DOI.

ISBN 978-80-905536-0-6 (Online)

ISSN 1805-9961 (Online)

Published by

Central Bohemia University, o.p.s.

Pod Vodárenskou věží 4,

18200 Praha 8,

Czech Republic

June 30, 2013

Printed in the Czech Republic with ISSN 1805-997X and ISBN 978-80-905536-1-3 (Print).

CBU International Conference Website

www.cbuic.cz,info@cbuni.cz

ojs.journals.cz

Publication of record for individual papers is online in the CBU Digital Library: ojs.journals.cz. This website is used to distribute the articles into various databases. For citing online articles please use E-ISSN (Online ISSN).

Copyright information:

Authors retain copyright and grant the journal right of first publication with the work simultaneously licensed under a Creative Commons Attribution License (Creative Commons Attribution License 3.0 - CC BY 3.0) that allows others to share the work with an acknowledgement of the work's authorship and initial publication in this journal.

Authors are able to enter into separate, additional contractual arrangements for the non-exclusive distribution of the journal's published version of the work (e.g., post it to an institutional repository or publish it in a book), with an acknowledgement of its initial publication in this journal.

Authors are permitted and encouraged to post their work online (e.g., in institutional repositories or on their website) prior to and during the submission process, as it can lead to productive exchanges, as well as earlier and greater citation of published work (See The Effect of Open Access).

\section{The conference Keynote speakers:}

Bohumil Havrland, Czech University of Life Sciences, Prague

Jan Čadil, Unicorn College, Prague

Tomáš Kroček, Charles University, Prague

Václav Nevrlý, VŠB-Technical University, Ostrava

Marek Jetmar, Central Bohemia University, Prague

Zdeněk Zelinger, J. Heyrovský Institute of Physical Chemistry, Academy of Sciences of the Czech Republic 
Table of contents

VII Conference chairs

VII Editorial committees

$\mathrm{X} \quad$ Introduction

\section{Economics and Business}

DOES THE UPPSALA INTERNATIONALIZATION MODEL EXPLAIN THE

INTERNATIONALIZATION PROCESS OF PROFESSIONAL BUSINESS SERVICE

FIRMS?

Magda Górska

http://dx.doi.org/10.12955/cbup.2013.9

COPULA BASED VAR APPROACH FOR EUROPEAN STOCKS PORTFOLIO

$9-18$

Mária Bohdalová, Michal Greguš

http://dx.doi.org/10.12955/cbup.2013.9

INDIVIDUAL RESISTANCE IN CHANGE PROCESS.

Đuro Horvat, Davor Perkov

http://dx.doi.org/10.12955/cbup.2013.10

VAR BASED RISK MANAGEMENT

Mária Bohdalová, Michal Greguš

http://dx.doi.org/10.12955/cbup.2013.11

AGRICULTURE AND ITS PLACE IN ECONOMIC DEVELOPMENT OF

UZBEKISTAN

Dilorom Tadjibaeva

http://dx.doi.org/10.12955/cbup.2013.12

SOCIAL ENTREPRENEURSHIP: CHALLENGE NOT ONLY FOR DEVELOPING COUNTRIES

BUT ALSO FOR THE EU.

Marek Jetmar

http://dx.doi.org/10.12955/cbup.2013.13

FORMS OF MANAGEMENT IN AGRICULTURE IN UZBEKISTAN: SCIENTIFIC AND THEORETICAL BASIS OF ITS EFFECTIVENESS.

Dilorom Tadjibaeva

http://dx.doi.org/10.12955/cbup.2013.14

SOME CONSIDERATIONS ABOUT THE NEW COMMUNICATIONS PARADIGM...... 61-68 Ivana Bulut

http://dx.doi.org/10.12955/cbup.2013.15

THE OPEN INNOVATION MODEL: EXPLAINING THE FACTORS THAT HINDER ITS IMPLEMENTATION IN THE ALBANIAN BANKING SYSTEM.

Besarta Vladi

http://dx.doi.org/10.12955/cbup.2013.16

EVALUATING MEASURES OF MARKET RISK IN CIRCUMSTANCES OF GLOBAL FINANCIAL CRISIS - EMPIRICAL EVIDENCE FROM FIVE COUNTRIES

Ivica Terzić, Marko Milojević

http://dx.doi.org/10.12955/cbup.2013.17 
EARLY SCHOOL LEADERSHIP CHALLENGES IN KAZAKHSTANI EDUCATIONAL

MANAGEMENT.

Anar Mukhtarova

http://dx.doi.org/10.12955/cbup.2013.18

TECHNOLOGICAL ENTREPRENEURSHIP OF SMALL AND MEDIUM BUSINESS IN THE REPUBLIC OF BULGARIA

AS A FACTOR FOR SUSTAINABLE DEVELOPMENT.

$91-96$

Angel Mirchev, Vesela Dicheva

http://dx.doi.org/10.12955/cbup.2013.19

CO-DETERMINATION POLITICS ON COMMERCIAL COMPANIES IN ALBANIA:

A COMPARATIVE STUDY.

Blerta Aliu

http://dx.doi.org/10.12955/cbup.2013.20

PROBLEMS OF MANAGEMENT OF PUBLIC-PRIVATE PARTNERSHIPS

104-109

Umar Burkhanov, Tulkin Atamuradov

http://dx.doi.org/10.12955/cbup.2013.21

EVALUATION OF KNOWLEDGE EFFECTIVENESS IN THE REAL ECONOMY......

$110-117$

Alzhanat Suleymankadieva

http://dx.doi.org/10.12955/cbup.2013.22

INVESTMENT IN EDUCATION AS A KEY DETERMINANT OF AGRICULTURAL

INSURANCE GROWTH.

Sofija Adzic, Dragan Stojic

http://dx.doi.org/10.12955/cbup.2013.23

\section{Social Sciences}

CORRUPTION ONSET IN THE NINETEENTH CENTURY IN KAZAKHSTAN........

Gaukhar Kaliyeva

http://dx.doi.org/10.12955/cbup.2013.24

CLASSIFICATION OF CRIMINAL GROUPS.

Natalia Romanova

http://dx.doi.org/10.12955/cbup.2013.25

DIFFERENCES IN SOCIAL AND MACHIAVELLIAN INTELLIGENCE BETWEEN THE MANAGEMENT STUDENTS

FROM THE CZECH AND SLOVAK REPUBLIC

Miroslav Frankovský, Zuzana Birknerová

http://dx.doi.org/10.12955/cbup.2013.26

THE USE OF CASE STUDIES IN THE BUSINESS ENGLISH LANGUAGE

TEACHING $.144-151$

Angela Strelchonok, Iveta Ludviga

http://dx.doi.org/10.12955/cbup.2013.27

METHODOLOGICAL BASIS OF DEVELOPMENT OF RESEARCH COMPETENCE OF SECONDARY SCHOOL

STUDENTS IN THE NETWORK RESEARCH COMMUNITY

Natalia Bezrukova, Anatoly Bezrukov

http://dx.doi.org/10.12955/cbup.2013.28 
CREATING INNOVATIVE PRODUCT IN FINANCIAL ENGLISH.

Elena Gavrilova, Kira Trostina

http://dx.doi.org/10.12955/cbup.2013.29

THE IDEA OF ONE WAY WORD FORMATION DICTIONARY

$169-173$

Irina Kovyneva

http://dx.doi.org/10.12955/cbup.2013.30

ACADEMIC MOBILITY AS THE SOURCE OF SCIENTIFIC-EDUCATIONAL

COOPERATION.

Gulnar Asanova, Kussaiyn Ryssaldy

http://dx.doi.org/10.12955/cbup.2013.31

JOSEPH SHERIDAN LE FANU: METAMORPHOSES AND INNOVATIONS IN GOTHIC

FICTION....

Jelena Brakovska

http://dx.doi.org/10.12955/cbup.2013.32

PROCESS MANAGEMENT IN RUSSIAN BUSINESS EDUCATION

$188-195$

Svetlana Korobeynikova, Ludmila Dukanich

http://dx.doi.org/10.12955/cbup.2013.33

INCLUSIVE EDUCATION IN KAZAKHSTAN: SELECTED ISSUES

$196-204$

Gulnar Zholtayeva, Assel Stambekova, Anara Alipbayeva, Gulnur Yerzhanova

http://dx.doi.org/10.12955/cbup.2013.34

INTEGRATION OF PEDAGOGIC TECHNOLOGIES AND CREATIVE TOOLS FOR ACHIEVING BALANCED COMPETENCE OF A POTENTIAL SPECIALIST.

Gulnara Akhmedyanova

http://dx.doi.org/10.12955/cbup.2013.35

OPENNESS OF A UNIVERSITY LIBRARY TO THE PUBLIC AS A KEY FOR FURTHER

DEVELOPMENT OF A SOCIETY.

Tian Yongmei, Wang Xiaodan

http://dx.doi.org/10.12955/cbup.2013.36

BRITISH AND RUSSIAN ATTITUDE TO NATURE REFLECTED IN FICTION: COGNITIVE AND LINGUOCULTURAL ANALYSIS.

Tamara Leontieva, Olga Filippova

http://dx.doi.org/10.12955/cbup.2013.37

PSYCHOLOGICAL COUNSELING AS A NEW INNOVATION AND PRACTICE IN HIGHER EDUCATION INSTITUTIONS IN ALBANIA.

Rudina Shkulaku

http://dx.doi.org/10.12955/cbup.2013.38

FP7 FUPOL PROJECT - INNOVATION IN POLICY SCIENCE

Egils Ginters, Artis Aizstrauts, Dace Aizstrauta, Ieva Lauberte, Miquel Angel, Piera Eroles,

Roman Buil, Peter Sonntagbauer, Susanne Sonntagbauer

http://dx.doi.org/10.12955/cbup.2013.39

SCIENTIFIC RESEARCH IN THE HIGHER EDUCATION IN ALBANIA IN LIEU OF THE BOLOGNA PROCESS: THE CASE OF THE EUROPEAN UNIVERSITY OF

TIRANA. $238-246$

Tomi Treska

http://dx.doi.org/10.12955/cbup.2013.40

PROCEEDings OF CBU INTERNATIONAL CONFERENCE Vol. 1

April 7-14, 2013, Prague, CzeCH Republic 
PERSONAL IDENTITY IN THE BALANCE BETWEEN WORK AND FAMILY

Dora Levterova

http://dx.doi.org/10.12955/cbup.2013.64

\section{Medicine and Pharmacy}

NEW METHOD FOR EXPERIMENTAL MODELING OF PANCREAS TRAUMAS FOR WISTAR

RATS AND CYTOKINE LEVEL CHANGES IN THESE MODELS.

254-257

Edgars Zarembo, Olga Mežale, Aleksandrs Mikitins, Leontine Antonovica, Jekaterina Petla,

Aigars Petersnons

http://dx.doi.org/10.12955/cbup.2013.41

PECULIARITIES OF PSYCHOLOGICAL WELL-BEING OF LITTLE TOWN AND METROPOLIS

STUDENTS: SOCIOCULTURAL ASPECT.

258-263

Irina Loginova, Oksana Gavrilyuk, Yulia Zhivaeva

http://dx.doi.org/10.12955/cbup.2013.42

SKIN CHANGES AND PECULIARITIES IN PATIENTS WITH METABOLIC

SYNDROME.

$264-271$

Jana Janovska, Aleksejs Zavorins, Julija Voicehovska, Regina Kleina, Janis Kisis,

Raimonds Karls, Aleksandra Voicehovska

http://dx.doi.org/10.12955/cbup.2013.43

STUDENTS' PERCEPTIONS OF ASPECTS AFFECTING MEDICAL EDUCATION

QUALITY....

Katya Peeva, Georgi Arabadzhiev, Georgi Yordanov

http://dx.doi.org/10.12955/cbup.2013.44

CHEMISTRY AND ANTITUMOUR ACTIVITY OF 5-BROMOURACILE'S

DERIVATIVES.

Elena Welchinskaya

http://dx.doi.org/10.12955/cbup.2013.45

STOMATOLOGIC IN PATIENTS WITH MALIGNANT NEOPLASMS OF MAXILLOFACIAL REGION UNDERGOING CHEMOTHERAPY AND

RADIOTHERAPY.

Olga Shpulina, Natalia Dorofeeva

http://dx.doi.org/10.12955/cbup.2013.46

ULTRASTRUCTURAL CHANGES OF THYROTROPIC CELLS IN THE DYNAMICS OF EXPERIMENTAL IMMUNOSTIMULATION.

Inessa Bobrysheva, Svetlana Kashchenko

http://dx.doi.org/10.12955/cbup.2013.47

MODERN INTEGRATION INTO THE WORLDWIDE EDUCATION PROCESS ON THE EXAMPLE OF THE TOXICOLOGICAL CHEMISTRY DISCIPLINE UNDER THE INFLUENCE

OF THE BOLOGNA SYSTEM IN UKRAINE 296-301

Iryna Nizhenkovskaya, Elena Welchinskaya

http://dx.doi.org/10.12955/cbup.2013.48

INFORMATION SYSTEM IN BLOOD CENTER: FIRST STEP FOR THE VIRAL

SAFETY $.302-306$

Kamal Tashtemirov, Sagit Imangazinov, Olga Tashtemirova

http://dx.doi.org/10.12955/cbup.2013.49 
Ludovit Gaspar, Matej Bendzala, Andrea Komornikova, Ivan Ocadlik, Michal Makovnik,

Peter Gavornik

http://dx.doi.org/10.12955/cbup.2013.50

POSITIVE STIGMA OF THE PEOPLE WITH DISABILITIES IN THE CZECH REPUBLIC AND

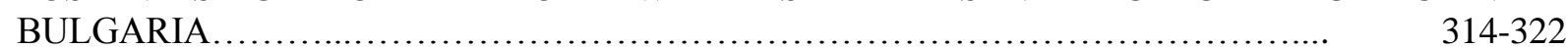

Vesela Kazashka, Dora Levterova, Margarita Ruseva

http://dx.doi.org/10.12955/cbup.2013.51

CRITERIA OF OCCUPATIONAL FITNESS FOR WORKERS OF COAL PRODUCTION

EXTREME PROFESSIONS

Aigul Ismailova, Sailaubai Onayev, Aizhan Ismailova

http://dx.doi.org/10.12955/cbup.2013.52

SYNCHRONIZATION OF IMMUNE AND PSYCHIC SYSTEMS ASSOCIATED WITH SOCIAL STRESS

Evgeniy Dotsenko, Marya Bogdanova, Tatyana Fisher, Sergey Petrov, Yuri Suhovey

http://dx.doi.org/10.12955/cbup.2013.53

EVALUATION OF TITANIUM AQUACOMPLEXGLITSEROSOLVATE AND OXYTOCIN IN

THE TREATMENT OF SOFT TISSUE WOUNDS IN EXPERIMENT

Olesya Mokhova

http://dx.doi.org/10.12955/cbup.2013.54

MICROELEMENT COMPOSITION OF THE TEENAGERS' BLOOD IN AN INDUSTRIAL

CITY.... $342-346$

Zulkiya Namazbaeva, Aigul Ismailova

http://dx.doi.org/10.12955/cbup.2013.55

ETHICS IN CLINICAL RESEARCH: IS ETHICS INVOLVED INTO THE PHARMACY STUDIES IN EUROPE?

Viera Žufková, Ján Klimas, Ján Kyselovič, Michal Vivoda, Marian Šuráb

http://dx.doi.org/10.12955/cbup.2013.56

\section{Natural Sciences and ICT}

PERSISTENT ORGANIC POLLUTANTS - PCBS AND DDTS IN FISH FROM DANUBE RIVER AND FROM BLACK SEA, BULGARIA.

Mona Stancheva, Stanislava Georgieva, Lubomir Makedonski

http://dx.doi.org/10.12955/cbup.2013.57

FAT SOLUBLE VITAMINS AND FATTY ACIDS COMPOSITION OF BLACK SEA

CYSTOSEIRA BARBATA. $362-367$

Veselina Panayotova, Mona Stancheva

http://dx.doi.org/10.12955/cbup.2013.58

EXAMINATION OF ORGANOCHLORINE PESTICIDES IN GOAT'S MILK

Julijana Tomovska, Vesna Hristova, Biljana Trajkovska, Nikola Gjorgievski

http://dx.doi.org/10.12955/cbup.2013.59

INTENSITY OF SOIL CONTAMINATION IN INDUSTRIAL CENTERS OF

KAZAKHSTAN $.374-380$

Amanzhol Iztileu, Olga Grebeneva, Maral Otarbayeva, Nina Zhanbasinova,

Ekaterina Ivashina, Bekbol Duisenbekov

http://dx.doi.org/10.12955/cbup.2013.60 
STEADY-STATE OSCILLATIONS OF TWO-BEARING CONSOLE ROTOR WITH MASS

IMBALANCE AND DISC MISALIGNMENT

Zharilkassin Iskakov

http://dx.doi.org/10.12955/cbup.2013.61

THE VARIATION OF COTTON OIL AND MISCELLA PARAMETERS IN THE ADSORBTION

REFINING PROCESS

389-399

Fayoza Suvanova, Jasur Farmonov, Oybek Ikromov, Azimjon Akhmedov

http://dx.doi.org/10.12955/cbup.2013.62

PHYSICAL AND CHEMICAL RESEARCH OF PROCESSES OF SALT FORMATION IN THE

WATER OF BALKASH LAKE. 400-411

Myrzabay Dzhetimov, Erlan Andasbayev, Ilias Esengabylov, Sayle Koyanbekova,

Erkyn Tokpanov

http://dx.doi.org/10.12955/cbup.2013.63 


\section{Conference chairs}

Petr Hajek, Central Bohemia University, Prague, Czech Republic

David Hartman, Unicorn College, Academy of Sciences of the Czech Republic, Charles University in Prague, Czech Republic

\section{Editorial committees}

\section{Editor-in-chief}

Dr. Petr Hajek, Vice-rector, Central Bohemia University, Prague, Czech Republic

\section{Editors}

Marie Zemková, Central Bohemia University

\section{Economics and business section committee}

Dr. Petr Hajek, Vice-rector, Central Bohemia University, Prague, Czech Republic

Prof. Drahomír Jančík, Institute of Economic and Social History, Faculty of Arts, Charles University, Prague \& Faculty of Business Administration, University of economics in Prague, Czech Republic Prof. Jiří Kleibl, rector of Unicorn College, Prague, Faculty of Business Administration, University of Economics, Prague, Czech Republic

Assoc. Prof. Miloš Kaňka, Faculty of Informatics and Statistics University of Economics in Prague \& The College of Polytechnics Jihlava, Czech Republic

Dr. Akram Jalal Karim, chairman of the Management Information System Department of College of Business and Finance at Ahlia University, Manama, Bahrain

Dr. Kholnazar Amonov, member of the board, Central Bohemia University, Prague, Czech Republic Assoc. Prof. Murtaz Kvirkvaia, Dean of the Faculty School of Business and Management, Grigol Robakidze University, Georgia

Hana Kristová, Senior Auditor, Deloitte, Prague, Czech Republic

Dr. Viktor Korček, Senior Management and Marketing Consultant \& East-African Project Manager, Prague, Czech Republic

Prof. Pacha Malyadri, Principal, Government Degree College, Osmania University, Hyderabad, Andhra Pradesh, India

Dr. Quang Van Tran, Faculty of Finance and Accounting, University of Economics in Prague, Czech Republic

Prof. Miroslav Tuček, retired professor, Banking expert, University of Economics in Prague, Czech Republic

Assoc. Prof. Kumaraj Sundar, Commerce Wing, Directorate of Distance Education, Annamalai University, India

Assoc. Prof. Jan Čadil, Unicorn College, Prague, Czech Republic

Khaled Zidan Ph.D., Finance department, Faculty of Economics and Social Studies, An-Najah

National University, Nablus, Palestine

Dr. Eva Vašková, Victor Pavlik Lawyers LLC. \& Prague Faculty of Law, Charles University in Prague, Czech Republic

Lukáš Horák, CEO's Strategic Analyses Department, Ceska Pojistovna Insurance Group Prague, Czech Republic

Vaidotas Matutis, State Tax Inspectorate, Ministry of Finance, Vilnius, Lithuania

Dr. Michal Brožka, Fixed-Income analyst Macroeconomics - Research Department Raiffeisenbank, Prague, Czech Republic

Patrik Just, Accounting and Law Specialist, Manifold Group, Plzeň, Czech Republic

Tomáš Voplakal, Charles University in Prague \& Faculty of Finance and Accounting, University of Economics in Prague \& Ernst and Young, Transaction Advisory services department, Czech Republic 
Valentina Shapoval, Department of Corporate Economics, National Mining University

Dnepropetrovsk, Ukraine

Dr. Jan Vorlíček, Unicorn College \& College of information Management and Business

Administration, Prague, Czech Republic

Dr. Eva Kaňková, University of Economics in Prague, Czech University of Life Sciences, Czech

Republic

Zuzana Svobodová, Department of Management and Marketing (ŠAVŠ), Škoda Auto University,

Mladá Boleslav, Czech Republic

Jerome Dumetz, Cross Cultural Management Specialist working inParis, Prague, Moscow and SanktPeterburg, organization Clamart, Paris, France

Assoc. Prof. Tomáš Pavelka, Faculty of Business Administration, University of Economics in Prague, Czech Republic

\section{Social sciences section committee}

Prof. Nino Kemertelidze, Vice-rector of Grigol Robakidze University (Heading Scientific Research Management Centre and Center of International Integration), Tbilisi, Georgia

Prof. Eduard Kubů, Faculty of Arts, Charles University \& University of Economics in Prague \& Unicorn College, Prague, Czech Republic

Dr. Eva Vašková, Victor Pavlik Lawyers LLC. \& Prague Faculty of Law, Charles University in

Prague, Czech Republic

Salih Seyhan, Communication Faculty, Journalism Department, Ataturk University, Turkey

Prof. Mikheil Gogatishvili, Programme leader of Public Administration, Social and Political sciences, Grigol Robakidze University, Tbilisi, Georgia

Prof. Arta Musaraj, Academicus-International Scientific Journal, Deputy Defence Minister, EtcEntrepreneurship Training Center, ex-rector of University of Pavaresia, Albania

Prof. Petr Marek, Department of Finance and Business Valuation, Executive board member of Acta

Oeconomica Pragensia, University of Economics in Prague, Czech Republic

Dr. Alexander Lesnik, Vice-rector, University of Economics and Management, Czech Republic

Pavel Král, Faculty of Management, University of Economics in Prague, Czech Republic

Prof. Milan Žák, Rector, University of Economics in Prague, Czech Republic

Daniel Tácha, editor-in-chief of Make Money, a journal published by Financial Media Group, Prague,

Czech Republic

\section{Medicine and pharmacy section committee}

Dr. Jana Staňurová, Fakultät für Biologie und Vorklinische Medizin, Universität Regensburg, Germany

Dr. Nakul Vinod Karkare, Orthopaedic surgeon and biomaterials engineer. Loma Linda, CA, United States

Dr. Eliška Potluková, 3rd Department of Medicine - Department of Endocrinology and Metabolism, First Faculty of Medicine, Charles University in Prague and General University Hospital in Prague,

Czech Republic

Assoc. Prof. Ekaterine Chkhartishvili, Human Histology and Embryology Department, AIETI Medical School (David Tvildiani Medical University), Pediatrician, Intensive Care Department, No.1 Pediatric Clinic, Tbilisi, Georgia

Prof. Liana Gogiashvili, Head of the Experimental Pathology Department, A. Natishvili Morphology Institute, Tbilisi, Georgia

Lucie Pieckova, Faculty of Food and Biochemical Technology Institute of Chemical Technology Prague (VSCHT Chemical University), Czech Republic

Dr. Eva Tůmová, 3rd Department of Medicine - Department of Endocrinology and Metabolism, First Faculty of Medicine, Charles University in Prague and General University Hospital in Prague, Czech Republic

Kateřina Bubáková, Faculty of Biomedical Engineering Czech Technical University in Prague; Motol University Hospital, Prague, Czech Republic 
Assoc. Prof. Izzet Yavuz, Faculty of Dentistry, University of Dicle in Diyarbakir, Turkey

Ondřej Lešetický, Department of Management (focus on Medical services), University of Economics in Prague, Czech Republic

Stanislav Janák, Production Director, Škrobárny a.s., Pelhřimov, Czech Republic

Dr. Helena Kristova, Lead clinical research associate, Chiltern International, Prague, Czech Republic

Prof. Olga Reshetnikova, Medical Faculty, Lugansk State Medical University, Ukraine

\section{Natural sciences and ICT section committee}

Dr. Václav Nevrlý, Institute of Thermomechanics, Academy of Sciences of the Czech Republic;

Faculty of Safety Engineering, VŠB-Technical University of Ostrava, Czech Republic

Dr. David Hartman, Unicorn College, Prague, \& Institute of Computer Science, Academy of Science of the Czech Republic, \& Department of Applied Mathematics, Charles University, Prague, Czech

Republic

Assoc. Prof. Zdeněk Zelinger, J. Heyrovský Institute of Physical Chemistry, Academy of Sciences of the Czech Republic, Prague, Czech Republic

Dr. Petr Bitala, Department of Fire Protection, Faculty of Safety Engineering, VŠB-Technical University of Ostrava, Czech Republic

Barbora Baudišová, Laboratory for Risk Research and Management, Faculty of Safety Engineering, \& Energy research center, VŠB-Technical University of Ostrava, Czech Republic

Jan Ptáček, Headmaster of the High School of Chemistry in Pardubice, Czech Republic

Dr. Jan Kamenický, Institute of new technologies and applied informatics, Faculty of Mechatronics, Informatics and Interdisciplinary studies, Liberec Technical University, Czech Republic

Lenka Hrušková, Institute of geochemistry, mineralogy and mineral resources, Faculty of Science, Charles University in Prague, Czech Republic

Dr. Viktor Goliáš, Institute of geochemistry, mineralogy and mineral resources, Faculty of Science, Charles University in Prague, Czech Republic

Dr. Oldřich Mužík, Research Institute of Agricultural Engineering, Prague, Czech Republic

Ladislav Torčík, CEO, NanoTrade Ltd., Olomouc, Czech Republic

Prof. Bohumil Havrland, Faculty of Tropical AgriSciences, \& editor-in-chief of Agricultura Tropica Et Subtropica an indexed journal of Czech University of Life Sciences, Prague, Czech Republic

Libor Voplakal, Faculty of Transportation Sciences, Czech Technical University in Prague, Czech

Republic

Michal Kökörčený, Head of Project Management Department (IT projects), Frederiksgroup \&

Unicorn College, Prague, Czech Republic

Dr. Y1lmaz Uyaroğlu, Electrical \& Electronics Engineering Department, Engineering Faculty, Sakarya University, Sakarya, Turkey

Dr. Ahmet Çifci, Electrical and Energy Department, Burdur Mehmet Akif Ersoy University, Burdur, Turkey

Dr. Uğur Erkin Kocamaz, Computer Technologies Department, Uludağ University, Karacabey, Turkey 


\section{Introduction}

We had the great honor of organizing the CBU International Conference 2013 (CBUIC 2013): Integration and Innovation in Science and Education in Prague, Czech republic. It was truly a great pleasure for us to greet a lot of participants from many different countries attending CBUIC 2013! We firmly believe that the conference will become an important international event in the field of crossindustry discussion about innovations in Education and Science.

CBUIC 2013 was organized by Central Bohemia University and Unicorn College, Prague, Czech Republic. Proceedings were published by Central Bohemia University.

5 cooperating organizations supported the conference. There were 57 papers accepted for presentation at CBUIC 2013, contributed by over 135 authors from more than 10 countries. We had four plenary speeches and several well-known scientists and experts, to give invited talks at different sessions.

The purpose of CBUIC 2013 was to provide a forum for the participants to report and review innovative ideas, with up-to-date progress and developments, and discuss the novel approaches to application in the field of their own research areas and discuss challenges of doing science and education.

We sincerely hope that the exchange of ideas on doing research, science and improving education will help the participants, and international cooperation sharing the common interest will be enhanced.

On behalf the Organization Committee of CBUIC 2013, we would like to heartily thank our cooperating organizations for all they have done for the conference. We would also like to thank the authors for their contribution to the proceedings; the participants and friends of CBUIC 2013, for their interest and efforts in helping us to make the conference possible; and the Editorial boards for their effective work and valuable advice, especially the CBUIC 2013 Secretariat and the CBU staff, for their tireless efforts and outstanding services in preparing the conference and publishing the Proceedings.

Petr Hájek, Central Bohemia University

David Hartman, Unicorn College

Conference chairs 